\title{
REGULARARTICLE
}

\section{CHARACTERIZATION OF SOME ALGERIANS AND FOREIGN LENTIL ACCESSIONS BY QUALITATIVE TRAITS \\ DJOUHER GAAD ${ }^{* 1,2}$, MERIEM LAOUAR ${ }^{2}$, FATIMA GABOUN 3 , AISSA ABDELGUERFI ${ }^{2}$}

\author{
${ }^{1}$ Department of Phytotechnie, National Height School of Agriculture, Algiers, Algeria \\ ${ }^{2}$ Division of Agriculture and Biotechnology, National Research Center for Biotechnology, Constantine, Algeria \\ 3National Institute of Agronomic Research, Regional Center of Rabat, B. P. 6356-Rabat-Instituts, Morocco
}

\begin{abstract}
In the present study an attempt has been made to characterize lentil accessions based on qualitative traits. There were variations among 44 lentil accessions. Erect growth habit was observed in $24 \%$ of the accessions where $8 \%$ were from Algeria. Conversely, prostrate growth habit was observed in $34 \%$ of the accessions. The majority of the remaining accessions (41.32\%) were intermediate. Stem with anthocyanin pigmentation was showed in $44 \%$ of the accessions, whereas, $56 \%$ had no pigmentation (green stem). About half of the accessions had grey green leaves (53\%) and 23\% of accessions were light green. Among the characters, flower color showed the highest variation. White flowers were observed in $64 \%$ accessions and violet flowers were found in $36 \%$ accessions. Flowers, with violet stripes in the standard petal (SVE) were observed in $44 \%$ accessions and the majority (56\%) lacked violet stripes. Yellow cotyledons were observed in $61 \%$ accessions, while the rest (39\%) had red cotyledons. The majority of accessions (81\%) were observed with brown testa while $14 \%$ were green and $5 \%$ had yellow testa. Absence of seed coat pattern was observed in $69 \%$ accessions. However, $8 \%$ accessions with spots, $5 \%$ with dots, $16 \%$ were marbled and the remaining $2 \%$ were complex. Flattened seed shape was observed in $60 \%$ of accessions. Conversely, globose shape was observed in $40 \%$ of the accessions, among of them $27 \%$ were from Algeria.
\end{abstract}

Keywords: Qualitative traits, Erect growth habit, Flower color, Lentil accessions, Algeria

\section{INTRODUCTION}

Lentil plant is mostly growing as an annual plant with branches covered with hairs. Stems are mainly narrow and light green [1]. Generally, there are cultivated as well as wild varieties [2]. Considerable variations among phenotypic traits have been reported earlier [3-5]. But there are certain limitations for this phenotypic characterization due to the environment impact on the structural traits [6]. Due to this fact, it is considered that, the phenotypic variations are results of both environmental and genetic attributes [7]. But the morphological markers are significant in analyzing hybridity and keeping genetic purity [4]. Keeping these in view, the objectives of this investigation was to characterize different lentil accessions from Algeria and abroad on the basis of qualitative traits.

\section{MATERIALS AND METHODS}

Two field experiments were conducted in two consecutive years of 2011/2012 and 2012/2013. Sowing was performed on December 9th, 2012 at INRAA station and on January 7 th, 2013 at ITGC station. A total of 44 accessions of cultivated lentil (Lens culinaris M.), comprised landraces and modern cultivars representing geographically and phenotypically wide variation, were used in this study. Among these, 18 were collected in Algeria (nine microsperma and nine macrosperma). In addition, a collection reference of 26 accessions including released popular cultivars and selected advanced lines was received from ICARDA ( 8 accessions), USDA (12 accessions) and ATFCC (6 accessions) under standard material transfer agreement during 2011. Relevant passport data of these accessions are given in table 1.

The first experiment carried out at experimental station of INRAA with $18.5 \mathrm{~m}$ altitude, in a sub-humid zone. The soil was clay-muddy with a $7.9 \mathrm{pH}$. A low temperature $\left(4^{\circ} \mathrm{C}\right)$ was recorded in February at seedling stage which caused certain leaf damage and cold injury.

The second field trial was located at the experimental farm of ITGC (Institut Technique des Grand Cultures), at Constantine district in the semi-arid region, about $713 \mathrm{~m}$ above the sea level. Similar to the first location cold injury was noticed during February when the temperature was below $5{ }^{\circ} \mathrm{C}$. A durum wheat crop had been grown during the previous season for both experimental locations.

\author{
Received 21 December 2017; Accepted 30 April 2018 \\ ${ }^{*}$ Corresponding Author \\ Djouher Gaad \\ Department of Phytotechnie, National Height School of Agriculture, Algiers, Algeria \\ Email: laouar_m@yahoo.fr
}

(T) This article is open access and licensed under the terms of the Creative Commons Attribution License (http://creativecommons.org/licenses/by/4.o/) which permits unrestricted, use, distribution and reproduction in any medium, or format for any purpose, even commercially provided the work is properly cited. Attribution - You must give appropriate credit, provide a link to the license, and indicate if changes were made. 
Table 1: Source of collection and country of origin of 44 lentil accessions

\begin{tabular}{|c|c|c|c|c|c|}
\hline $\mathbf{N}$ & Accessions Code & Accession name & Status & Origin & Source of collection \\
\hline 01 & ALG3. lens & Unknown & Population & Algeria & Farmer/Algeria \\
\hline 02 & ALG4. lens & Unknown & Population & Algeria & Farmer/Algeria \\
\hline 03 & ALG6. lens & Syrie229_1 & $\begin{array}{l}\text { Cultivated } \\
\text { variety }\end{array}$ & Algeria & ITGC/Algeria \\
\hline 04 & ALG7. lens & Balkan755 & $\begin{array}{l}\text { Cultivated } \\
\text { variety }\end{array}$ & Algeria & ITGC/Algeria \\
\hline 05 & ALG8. lens & Ibla & $\begin{array}{l}\text { Cultivated } \\
\text { variety }\end{array}$ & Algeria & ITGC/Algeria \\
\hline 06 & ALG12. lens & Blande de Chili_1 & $\begin{array}{l}\text { Cultivated } \\
\text { variety }\end{array}$ & Algeria & Farmer/Algeria \\
\hline 07 & ALG15. lens & Unknown & Population & Algeria & Farmer/Algeria \\
\hline 08 & ALG16. lens & Unknown & Population & Algeria & Farmer/Algeria \\
\hline 09 & ALG18. lens & Radjas & $\begin{array}{l}\text { Cultivated } \\
\text { variety }\end{array}$ & Algeria & ITGC/Algeria \\
\hline 10 & ALG19. lens & Flip $9031 \mathrm{C}$ & Hybrid line & Algeria & ITGC/Algeria \\
\hline 11 & ALG21. lens & Setif628 & $\begin{array}{l}\text { Cultivated } \\
\text { variety }\end{array}$ & Algeria & ITGC/Algeria \\
\hline 12 & ALG22. lens & Flip $48 \mathrm{~L}$ & Hybrid line & Algeria & ITGC/Algeria \\
\hline 13 & ALG23. lens & Flip 97-11C & Hybrid line & Algeria & ITGC/Algeria \\
\hline 14 & ALG25. lens & Metropole_3 & $\begin{array}{l}\text { Cultivated } \\
\text { variety }\end{array}$ & Algeria & Farmer/Algeria \\
\hline 15 & ALG28. lens & Unknown & Population & Algeria & Farmer/Algeria \\
\hline 16 & ALG29. lens & Unknown & Population & Algeria & Farmer/Algeria \\
\hline 17 & ALG3o. lens & Metropole_4 & $\begin{array}{l}\text { Cultivated } \\
\text { variety }\end{array}$ & Algeria & Farmer/Algeria \\
\hline 18 & ALG31. lens & Unknown & Population & Algeria & Farmer/Algeria \\
\hline 19 & $\mathrm{IG}_{5511}$ & Unknown & Breeding & Syria & ICARDA \\
\hline 20 & IG1647 & Cundina & material & Colombia & ICARDA \\
\hline 21 & IG26 & ILL26 & Unknown & Syria & ICARDA \\
\hline 22 & IG1828 & ILL1828 & Unknown & Bio & ICARDA \\
\hline 23 & IG8 & ILL8 & Unknown & Bio/Chili & ICARDA \\
\hline 24 & IG572 & ILL572 & Improved & Jordan & ICARDA \\
\hline 25 & $\mathrm{IG}_{5160}$ & ILL5160 & cultivar & Turkey & ICARDA \\
\hline 26 & IG4872 & DEU146 & Breeding & Jordan & ICARDA \\
\hline 27 & PI431640 & ILL1017 & material & Afghanistan & USDA \\
\hline 28 & PI619099 & Mason & Breeding & Iran & USDA \\
\hline 29 & PI374120 & ILL1941 & material & USA & USDA \\
\hline 30 & PI490289 & Mariette & Breeding & Morocco & USDA \\
\hline 31 & PI486127 & Unknown & material & France & USDA \\
\hline 32 & PI320936 & Daghestan & Hybrid line & USA & USDA \\
\hline 33 & PI468902 & Populacao & Improved & Russia & USDA \\
\hline 34 & PI320937 & ILL5O5 & cultivar & /Brazil & USDA \\
\hline 35 & PI297787 & ILL319 & Other & Germany & USDA \\
\hline 36 & PI533690 & PARDINA & Cultivar & Greece & USDA \\
\hline 37 & PI472126 & $33-0690000$ & Breeding & Spain & USDA \\
\hline 38 & PI374119 & ILL1940 & material & India & USDA \\
\hline 39 & V69-10010 & Flash & Unknown & Morocco & ATFCC \\
\hline 40 & ILL5722 & Digger & Unknown & Australia & ATFCC \\
\hline 41 & ILL5728 & Cobber & Unknown & Australia & ATFCC \\
\hline 42 & ILL5823 & Matilda & Unknown & Australia & ATFCC \\
\hline 43 & ILL7180 & Nugget & Unknown & Australia & ATFCC \\
\hline \multirow[t]{9}{*}{44} & Unknown & Cassab & Unknown & Australia & ATFCC \\
\hline & & & Unknown & Australia & \\
\hline & & & Improved & & \\
\hline & & & cultivar & & \\
\hline & & & Improved & & \\
\hline & & & cultivar & & \\
\hline & & & Improved & & \\
\hline & & & cultivar & & \\
\hline & & & $\begin{array}{l}\text { Improved } \\
\text { cultivar }\end{array}$ & & \\
\hline
\end{tabular}


Table 2: Descriptors used for morphological assessment for qualitative traits of lentil in the study [8, 9]

\begin{tabular}{|c|c|c|c|c|c|}
\hline $\mathbf{N}$ & Descriptors & $\begin{array}{l}\text { Acrony } \\
\text { ms }\end{array}$ & Definition & $\begin{array}{l}\text { When } \\
\text { measured }\end{array}$ & Unit \\
\hline & & & Qualitative traits & & \\
\hline 1 & Growth habit & GHA & $\begin{array}{l}\text { The branching pattern recorded on } \\
\text { plot basis }\end{array}$ & After flowering & $\begin{array}{l}\text { Erect }=1 \\
\text { Intermediate }=3 \text { Prostate }=5\end{array}$ \\
\hline 2 & $\begin{array}{l}\text { Stem } \\
\text { pigmentation }\end{array}$ & SPG & Color at the base of the stem & Seedling stage & Absent $=1$ Present $=9$ \\
\hline 3 & Leaf color & LCL & Recorded on plot basis & $50 \%$ flowering & $\begin{array}{l}\text { Dark green }=3 \text { Light green }=5 \\
\text { Grey green }=7\end{array}$ \\
\hline 4 & Flower color & FLC & Recorded on plot basis & First few flowers & $\begin{array}{l}\text { White }=1 \text { Pink }=2 \\
\text { Blue }=3\end{array}$ \\
\hline 5 & $\begin{array}{l}\text { Violet stripes of } \\
\text { standard }\end{array}$ & SVE & $\begin{array}{l}\text { Flowers white petals with blue } \\
\text { veins }\end{array}$ & First few flowers & Absent $=1$ Present $=9$ \\
\hline 6 & Plant vigor & PLV & Recorded on plot basis & First few flowers & Weak $=3$ Medium $=5$ Strong $=7$ \\
\hline 7 & Cold tolerance & CTL & $\begin{array}{l}\text { Damage caused to leaf manifested } \\
\text { by violet color }\end{array}$ & Seedling stage & No symptom $=1$ Plant killed $=9$ \\
\hline 8 & Cotyledon color & CCL & Cotyledon color of 100 good seeds & $\begin{array}{l}\text { Freshly } \\
\text { harvested seeds }\end{array}$ & Yellow $=1$ Orange $=2$ Green $=3$ \\
\hline 9 & Seed ground color & SGC & $\begin{array}{l}\text { Ground color of testa of } 100 \text { good } \\
\text { seeds }\end{array}$ & $\begin{array}{l}\text { Freshly } \\
\text { harvested seeds }\end{array}$ & $\begin{array}{l}\text { Brown }=1 \\
\text { Yellow }=2 \text { Green }=3 \\
\text { Grey }=4 \\
\text { Black }=5\end{array}$ \\
\hline $\begin{array}{l}1 \\
0\end{array}$ & Seed coat pattern & $\mathrm{SCP}$ & Pattern of testa of 100 good seeds & $\begin{array}{l}\text { Freshly } \\
\text { harvested seeds }\end{array}$ & $\begin{array}{l}\text { Marbled }=1 \text { Striped }=2 \\
\text { Dotted }=3\end{array}$ \\
\hline $\begin{array}{l}1 \\
1\end{array}$ & Seed shape & $\mathrm{SSH}$ & Seed shape of 100 good seeds & $\begin{array}{l}\text { Freshly } \\
\text { harvested seeds }\end{array}$ & $\begin{array}{l}\text { No pattern }=4 \text { Complex }=5 \\
\text { Globus }=1 \text { Flattened }=2\end{array}$ \\
\hline
\end{tabular}

The experiments were carried out following an Alpha Lattice design with four replicates. Unit plot size was 3 $\mathrm{m}^{2}(3 \mathrm{~m} \times 1 \mathrm{~m})$. Row to row and plant to plant distances were $50 \mathrm{~cm}$ and $10 \mathrm{~cm}$, respectively. All recommended cultural practices and plant protection measures were followed to raise a healthy crop.

The standard descriptors for lentil [8] and UPOV descriptors [9] have been used as guidelines in the phenotypic characterization. Observations were recorded from 4 replications of 3 plants. The details of all traits taken into account, is given in table 2.

\section{RESULTS AND DISCUSSION}

The frequencies for all qualitative characters are summarized in Table 3. Lentil genotypes showed large differences in growth habit (GHA). Erect growth habit was observed in $24 \%$ of the accessions. Conversely, prostrate growth habit was observed in $34 \%$ of the accessions. The majority of the remaining accessions (41.32\%) were intermediate. In this study, $44 \%$ of the accessions showed stem with anthocyanin pigmentation (SPG), whereas, $56 \%$ had no pigmentation (green stem). The stem color of other accessions from ICARDA, USDA, and ATFC were either purple or green. The green color of the leaf (LCL) has three variants: light green, gray green and dark green. About half of the accessions had grey green leaves (53\%) and $23 \%$ of accessions were light green. The dark green color was observed in $25 \%$ of accessions. White flowers were observed in $64 \%$ accessions and violet flowers were found in $36 \%$ accessions. Flowers, with violet stripes in the standard petal (SVE) were observed in $44 \%$ accessions and the majority (56\%) lacked violet stripes.

In both experiments, plants were affected by cold that occurred in February. Observation of cold tolerance revealed that response to cold among genotypes varied from one accession to another. While the majority of accessions showed moderate symptoms (95\%), few accessions (5\%) were susceptible to the cold and died, which was the case for ALG16 (microsperma), IG5511 (macrosperma) from Syria, IG516o (microsperma) from Jordan and IG4872 (microsperma) from Afghanistan. The local cultivated varieties: ALG7 (Balkan755: microsperma), ALG8 (Ibla: macrosperma), ALG18 (Radjas: microsperma), ALG21 (Setif 628: microsperma), a hybrid line ALG22 (microsperma), and two accessions from abroad: IG572 (microsperma) from Turkey and PI374120 (macrosperma) from Morocco did not show any damage.

Yellow cotyledons were observed in $61 \%$ accessions, while the rest (39\%) had red cotyledons. The majority of accessions (81\%) were observed with brown testa (STC) while $14 \%$ were green and $5 \%$ had yellow testa. The majority of Algerian accessions had brown testa (35.06\%). Absence of seed coat pattern (SCP) was observed in 69\% accessions and 30\% were from Algeria. However, 8\% accessions had spots, $5 \%$ had dots, $16 \%$ were marbled and the remaining $2 \%$ were complex. Flattened seed shape (SSH) was observed in $60 \%$ of accessions. Conversely, globose shape was observed in $40 \%$ of the accessions, among of them $27 \%$ were from Algeria. 
Table 3: Frequency distribution of 11 qualitative traits assessed in 43 lentil accessions

\begin{tabular}{|c|c|c|}
\hline Character & Description state & Frequency \% \\
\hline \multirow[t]{3}{*}{ Growth habit } & Erect $=1$ & 24.38 \\
\hline & Intermediate $=3$ & 41.32 \\
\hline & Prostate $=5$ & 34.30 \\
\hline \multirow[t]{2}{*}{ Stem pigmentation } & Absent $=1$ & 56.21 \\
\hline & Present $=9$ & 43.79 \\
\hline \multirow[t]{3}{*}{ Leaf color } & Dark green $=3$ & 29.43 \\
\hline & Light green $=5$ & 17.09 \\
\hline & Grey green=7 & 53.48 \\
\hline \multirow[t]{3}{*}{ Flower color } & White $=1$ & 64.43 \\
\hline & Blue $=3$ & 00.00 \\
\hline & Violet $=4$ & $35 \cdot 57$ \\
\hline \multirow[t]{2}{*}{ Violet stripes of standard } & Absent $=1$ & 56.50 \\
\hline & Present $=9$ & 43.50 \\
\hline \multirow[t]{3}{*}{ Cold tolerance } & No symptom=1 & 04.12 \\
\hline & Moderate symptom & 95.08 \\
\hline & Plant killed $=9$ & 00.79 \\
\hline \multirow[t]{3}{*}{ Cotyledon color } & Yellow=1 & 61.30 \\
\hline & Orange $=2$ & 38.69 \\
\hline & Green $=3$ & 00.00 \\
\hline \multirow[t]{5}{*}{ Seed ground color } & Brown $=1$ & 81.33 \\
\hline & Yellow $=2$ & 02.36 \\
\hline & Green $=3$ & 13.90 \\
\hline & Grey=4 & 00.00 \\
\hline & Black $=5$ & 00.00 \\
\hline \multirow[t]{5}{*}{ Seed coat pattern } & Marbled=1 & 16.39 \\
\hline & Striped $=2$ & 08.28 \\
\hline & Dotted $=3$ & 04.58 \\
\hline & No pattern $=4$ & 68.55 \\
\hline & Complex $=5$ & 02.36 \\
\hline \multirow[t]{2}{*}{ Seed shape } & Globus $=1$ & 40.07 \\
\hline & Flattened=2 & 59.92 \\
\hline
\end{tabular}

\section{DISCUSSION}

In the present study, the nine qualitative traits allowed the discrimination of the accessions. The accessions included very different growth habit from prostrate, intermediate to erect growth habit. According to Erskine and Goodrich [10], lentil varieties vary in growth habit. The stems are generally light green in color but in several genotypes they may have varying degrees of anthocyanin pigmentation, ranging from only on the basal parts to the whole of the stems, while in others it could be completely absent [11]. In Italy, [12] the presence of anthocyanin pigmentation at the base of plants grown in dense stands in the majority of the entries. Contrary to our finding, the majority of accessions presented stem without anthocyanin pigmentation. In a collection of lentil landraces comprising 39 genotypes from the South East of Turkey, most of the landraces had seedling-stem pigmentation [13]. The local accessions present light green color foliage, compared to accessions from Asia (India, Afghanistan and Iran) and Europe (Spain, Germany, France and Turkey) which presented grey color of leaf. It is clear from previous studies, the foliage of Asian group, named grex pilosae, is grey green because of the presence of soft hairs, and it contrasts with the green color common for lentil [14,15]. Those results correlated with our finding where only a few accessions mainly from Morocco and USA presented dark foliage color. Flower color is important trait to characterize [4]. The standard petal is white, pink, purple, light purplish blue, or pale blue [16]. In this study, the majority of accessions had white flowers including some Algerian accessions. The remaining accessions had violet flower color. According to Erskine and Witcombe [17], lentil plants develop blue or pink flowers occasionally, that persist for one generation and do not develop in subsequent generations.

Another study [18] classified the ground color of testa. The predominance of brown grain tasta in local accessions is based on quality acceptance dictated by farmer and consumer preference. Also, in another study [19] in the global wild annual Lens taxa, originating from twentyseven countries stated that the ground color of testa was mostly grey and brown. While, testa ground color was green in $90 \%$ of one hundred and one Spanish landraces of lentil [18]. One of the earlier research [21] reported that brown testa was completely dominant over tan testa. There are three kinds of cotyledon in lentil, red, green and yellow. Cotyledon color is an important trait for breeding lentil based on consumer preference in different regions [22]. Most Algerians accessions prefer yellow cotyledons. The majority of accessions from Asia (India, Afghanistan, Syria and Jordan) had red cotyledons. According to one study [23], there are strong preferences for small seed types with red cotyledons among consumers in the South Asian countries. Red cotyledon color is preferred for consumption in South Asia [5]. In both local and introduced accessions we found the two types of seed shape, flattened and globular. Lentil seeds may have a globose shape (diameter: thickness ratio ranging from 1.5 to 2.5) or flattened (diameter: thickness ratio ranging from 2.5 to 4 ) [11].

Cold tolerance was recorded for all the genotypes in this study and no relationship was found between seed type and cold tolerance. Although, large seeded varieties had 
greater cold tolerance in comparison with small seed varieties [23]. They also stated that considering adaptation to other climatic conditions, pilosae germplasm (India and Pakistan) is strikingly more susceptible to cold damage than germplasm from West Asia (Syria and Jordan). While, in this study the Syrian and Jordan accessions were susceptible to cold damage. Previous study [3] reported that large number of plant with prostrate growth habit and purple pigment of the stem were injured by cold in the field. Contrary to our finding, all susceptible accessions had a stem without pigment with different growth habit (erect, intermediate and prostrate).

\section{CONCLUSION}

Significant differences among the accessions for different qualitative characters indicated variation among the accessions favorable for their use in future breeding programs.

\section{REFERENCES}

1. Muehlbauer FJJ, Cubero I, and Summerfield RJ. Lentil (Lens culinaris Medik.). In: Summerfield RJ, Roberts EII. (eds). Grain Legume Crops. Grafton Street, London, UK.1985;266-311.

2. Sandhu JS, Singh S. History and origin. In: Yadav S, McNeil DL, Stevenson PC, (ed) Lentil an ancient crop for modern times. Springer, the Netherlands.2007:1-10.

3. Asghar A, Johnson DL. Association of Growth Habit and Anthocyanin Pigment with Winter Hardiness in Lentil. Pakistan Journal of Biological Sciences. 1999;2:1292-1295.

4. Roy S, ISlam MA, Sarker A, Ismail MR, Rafil MY, Mondal MMA, Malek MA. Morphological chracterization of lentil accessions: Qualitative characters. Bangladesh J. Bot. 2012;2:187-190.

5. Pratap A, Kumar J, Kumar S. Evaluation of wild species of lentil for agro-morphological traits. Legume Res. 2014;1:11-18.

6. Dalamu M, Behera TK, Gaikwad AB, Saxena S, Bharadwaj C, Munshi AD. Morphological and molecular analyses define the genetic diversity of Asian bitter gourd (Momordica charantia L.). Australian Journal of Crop Science. 2012;2:261-267.

7. El-esawi MA. Genetic diversity and evolution of Brassica genetic resources : from morphology to novel genomic technologies, a review. Plant Genetic Resources. 2016:1-12.

8. IPGRI. Descriptors for lentil (Lens culinaris M.). International Plant Genetic Resources Institute, Rome, Italy. 1985;19p.

9. UPOV. Lentille: principes directeurs pour la conduite de l'examen de la distinction, de l'homogénéité et de la stabilité. Union internationale pour la protection des obtentions végétales. TG/210/2(proj.4). Geneve. 2003.

10. Erskine W, Goodrich WJ. Variability in lentil growth habit. Crop Science. 1991;31:1040-1044.

11. Saxena MC. Plant Morphology, Anatomy and Growth Habit. In Erskine W, Muehlbauer FJ, Sarker A, Sharma B. (ed). The Lentil: Botany, Production and Uses. CAB Intern, Cambridge. 2009:pp. 34-46.

12. Torricelli R, Silveri DD, Ferradini N, Venora G, Veronesi F, Russi L. Characterization of the lentil landrace Santo Stefano di Sessanio from Abruzzo, Italy. Genetic Resources and Crop Evolution. 2012;2:261-276.

13. Toklu F, Biçer T, Karaköy T. Agro-morphological characterization of the Turkish lentil landraces. African Journal of Biotechnology. 2009;17:4121-4127.

14. Erskine W, Chandra S, Chaudhry M, Malik IA, Sarker A, Sharma B, Tyagi MC. A bottleneck in lentil: widening its genetic base in South Asia. Euphytica. 1998;101:207-211.

15. Kumar M, Mishra SK, Tyagi MC, Singh SP, Sharma B. Linkage between genes for leaf colour, plant pubescence, number of leaflets and plant height in lentil (Lens culinaris Medik.). Euphytica. 2005;45:41-48.

16. Wilson VE, Hudson LW. Inheritance of lentil flower colour. The Journal of Heredity. 1978;69:129-130.

17. Erskine W, Witcombe JR, Lentil Germplasm Catalog (Internatio). Aleppo, Syria, 1984.

18. Singh AK, Kumar P, Singh J, Rani R, Rani A, Shukla P, Misra P. Diversity analysis of lentil (Lens culinaris Medik.) germplasm using morphological markers. Asian Journal of Bio Science. 2014;1:39-42.

19. Emami MK, Sharma B. Inheritance of black testa colour in lentil (Lens culinaris Medik.). Euphytica. 2000;115:43-47.

20. Mishra S, Sharma B, and Sharma KS. Genetics and cytogenetics of lentil. In: Yadav S, McNeil DL, Stevenson PC. (ed.) Lentil an ancient crop for modern times. Springer, the Netherlands. 2007;pp. 187-208.

21. Lazaro A, Ruiz M, Rosa D, Mart I. Relationships between agro/morphological characters and climatic parameters in Spanish landraces of lentil (Lens culinaris Medik.). 2001;48:239-249.

22. Rahman MM, Sarker A, Kumar S, Ali A, Lutfor M. Breeding for Short Season Environments. In Erskine W. Muehlbauer FJ, Sarker A, Sharma B. (ed). The Lentil: Botany, Production and Uses. CAB Intern, Cambridge. 2009;pp. 121-136.

23. Erskine W, Myveci K, Izgin N. Screening a world lentil collection for cold tolerance. LENS Newsletter. 1981;8:5-8. 